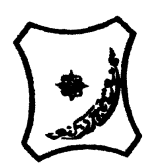

Bayero Journal of Pure and Applied Sciences, 12(1): 63 - 69

Received: July, 2018

Accepted: December, 2018

ISSN $2006-6996$

\title{
EFFECT OF EXTRACTION METHODS ON THE QUALITY OF GROUNDNUTOIL IN SOME SMALL-SCALE INDUSTRIES IN KANO STATE
}

\author{
*Ahmad R.K., Kabir M., Muhammad A. I.,Lawan I., and **Ahmad, H. K \\ Department of Agricultural and Environmental Engineering, Faculty of Engineering, Bayero University \\ Kano \\ ** Department of Plant Biology, Faculty of Life Science, Bayero University Kano \\ *Corresponding Author: rkahmad.age@buk.edu.ng
}

\begin{abstract}
Groundnut oil is the cheapest and most extensively used vegetable oil in many countries.Different methods were used to obtain the oil from the groundnuts, which include traditional or manual, mechanical (with or without roasting) and solvent extraction methods. There are some variations in the extraction methods that may affect both the yield and the quality of the extracted oil. In this study, the effect of extraction methods on the quality of groundnut oil in selectedsmall-scale industries at Sharada, Kano municipal LGA, Kano State was conducted. Two extraction methods were identified, after carrying out an investigation using a structured questionnaire. These are mechanicallyextracted without roasting (M1) and mechanical extraction with roasting (M2) methods. For comparison, the traditional extraction method (M3) usually applied by local extractors was also studied.An ANOVA was used to analyze the data. The physicochemical properties of the samples were analyzed and compared to NAFDAC standards. Iodine value (IV), Saponification value (SV), Specific gravity (SG), Acid value (AV) and Peroxide value (PV) were determined. The findings revealed that IV, SV and PV were highly significant. M2 was found to have the highest IV (26.56 mg/g) and PV (5.7 meq/kg) while M1 has the highest SV (106.605 mgKOH/g). M3 was having the least IV (5.92 $\mathrm{mg} / \mathrm{g}), \mathrm{SV}(44.835 \mathrm{mgKOH} / \mathrm{g})$ and PV $\left(0.75 \mathrm{meqkg}^{-1}\right)$. The values obtained for $A V$, $P V$ and SG conform to the NAFDAC standard in all the three methods, while those for IV and SV declined. To achieve the best quality results, the study concludes that the mechanical extraction method with roasting is the best method to employ.

KEYWORDS: Extraction methods; Groundnut Oil; Physicochemical properties; Oil quality; Small-scale Industries.
\end{abstract}

\section{INTRODUCTION}

Groundnut (Arachis hypogaea L.) also called peanut, is a staple food in many developing countries. It is a very important oilseed and food crop as it supplies a plentiful source of highquality edible oil (45-50\%), easily digestible protein (23-25\%), minerals, and vitamins.It was placed 13th among the food crops and annual oilseed crops in the world (ICRISAT and East Timor, 2003).Its high oil and protein contents serve important needs for food, energy, and industrial purposes. Approximately $75 \%$ of global Groundnut production is used for the extraction of edible oil. Hence, naming it one of the significant roots of vegetable oil, along with soybean, sunflower and palm oil (FAO, 2002; Vara-Parasad et al., 2011). Groundnut oil is the cheapest and most extensively used vegetable oil in many countries. It is used for general cooking, for margarine and salads, for deep frying, for shortening in pastries and bread, for pharmaceutical and cosmetic products. It is likewise employed as a lubricant and emulsion for insecticides and fuel for diesel engines (VaraParasad et al., 2011).

The production of oil from groundnut involves postharvest operations, including shelling, roasting and pressing (Ibrahim and Onwualu, 2005). Various methods have been used to draw out the oil from the groundnuts. These may include traditional or manual, mechanical (with or without roasting) and solvent extraction methods. Variation in the extraction methods may affect both the yield and or the quality of the extracted oil (Matola et al., 2015). 
BAJOPAS Volume 12 Number 1, June, 2019

Small-scale industries play an important role in groundnut oil extraction. It is common knowledge that small-scale food processing is normally restrained by an act of problems such as poor understanding of quality requirements, inadequate hygiene, inadequate processing skills, special knowledge in both local and international food standards and much more. These food processing related constraints affect the small-scale industries ultimately in most instances resulting in products with low quality whose safety cannot be guaranteed (Matolaet al., 2015). Some of the parameters used to assess the quality of oils according to Chabiri et al., (2009) include Moisture content, Smoke point, Saponification value, Acid value, Iodine value and Peroxide value, Specific gravity and Refractive Index.And then, it becomes vital while selecting an appropriate extraction method to know which among the methods produces a better quality of the oil.Thus, the survey was conducted to assess the effectiveness of extraction methods on the physicochemical properties of groundnut oil extracted at Sharada small-scale industries at Kano Municipal LGA, Kano state, and compared with NAFDAC standard. The specific objectives were:

1. To study the extraction methods utilized by the Sharada small-scale industries.

2. To determine the physicochemical properties of the groundnut oil samples produced by the small-scale industries and samples extracted by themanual method.

3. To compare the physicochemical properties of all the samples with standard physicochemical properties recommended by NAFDAC.

The study would help in the selection and/or improvement of the methods or processes involved in the oil extraction for better quality and, as well, help the small-scale industries to attain both national and international market values.

\section{METHODOLOGY}

Survey of the small scale industries and their extraction methods

Ten (10) small scale industries were selected using a random selection and each was given one copy of the questionnaire for assessment. The extraction processes used by the selected small-scale industries were also investigated using the questionnaire.

The structured questionnaire entails the following details: pre-extraction stages, the materials, and equipment used in the qualification determination, specifications of the extraction machine, operational capacity and details of the machinery operators.

\section{Sampling method}

Samples of the groundnut oil were collected from the selected study area using the following extraction methods; mechanical extraction method without roasting (M1), mechanical extraction method with roasting (M2) and Traditional extraction method (M3). Samples of the groundnut oil collected were extracted from Mai Bargo groundnut variety.

Determination of the Physicochemical Properties

Iodine value (IV), Saponification value (SV), Acid value $(A V)$, Peroxide value (PV) and Specific gravity (SG) were determined according to standard methods of AOCS (1998).

Iodine Value (IV):The method was based on the treatment of a known weight of oil/fat with a known volume of a standard solution of iodine monochloride $(\mathrm{ICl})$. Excess $\mathrm{ICl}$ was reacted with potassium iodide (KI) and the iodine liberated was titrated against $\mathrm{Na}_{2} \mathrm{~S}_{2} \mathrm{O}_{3} \cdot 5 \mathrm{H}_{2} \mathrm{O}$ with starch as an indicator. $0.3 \mathrm{~g}$ of the groundnut oil was weighed accurately. $10 \mathrm{ml}$ of $\mathrm{CCl}_{4}$ and $25 \mathrm{ml}$ of Wits solution was added successively and the flask was vortexed and allowed to stand in a dark cupboard for 1 hour. $15 \mathrm{ml}$ of $10 \%$ potassium iodide and $100 \mathrm{ml}$ of distilled water were added followed by $1 \mathrm{ml}$ of starch solution. It was titrated against $0.1 \mathrm{~N} \mathrm{Na} \mathrm{S}_{2} \mathrm{O}_{3}$ until the blue color disappeared, indicating an endpoint. A blank solution was titrated without the oil sample. The iodine value was then calculated using equation 3.1

$$
\text { Iodine value }=\frac{(b-a) \times N \times 1.269 \times 100}{W} \ldots \ldots . .1
$$

Where $\mathrm{b}=$ blank titer value, $\mathrm{a}=$ sample titer value, $\mathrm{N}=$ normality of thiosulphate, $\mathrm{W}=$ weight of sample.

Saponification Value (SV): $0.5 \mathrm{~g}$ of the oil was weighed in a quick-fit-reflux flask and $25 \mathrm{ml}$ alcoholic $\mathrm{KOH}$ was added. It was refluxed for 30 minutes so that it gets a simmer. The flask was cooled and $1 \mathrm{ml}$ of phenolphthalein indicator was added and titrated against $0.5 \mathrm{~N} \mathrm{HCl}$. The values were calculated using equation 2 below: Saponification value $=$

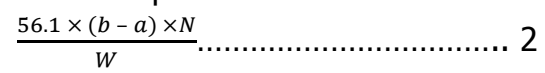

Where $\mathrm{W}=$ weigh of sample $=0.5 \mathrm{~g}, \mathrm{~b}=$ blank titre value, $\mathrm{a}=$ sample titre value, $\mathrm{N}=$ Normality of $\mathrm{HCl}$.

Determination of Specific gravity (SG): Pycnometer (i.e. specific gravity bottle) was used in measuring the specific gravity. Cleaned, dried Pycnometer was weighed. It was filled with distilled water maintained at $20^{\circ} \mathrm{C}$ and reweighed again. 
BAJOPAS Volume 12 Number 1, June, 2019

The bottle was emptied, dried and filled with oil and weighed. The value was calculated using equation 3

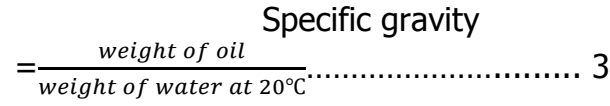

Determination of Acid value: Acid value of oil was determined by titration of a known weight of the oil against $0.25 \mathrm{MNaOH}$ using phenolphthalein as an indicator. The groundnut oil $(1.0 \mathrm{~g})$ was weighed in a conical flask and $50 \mathrm{ml}$ of denatured alcohol was added, vortexed and 2 drops of phenolphthalein indicator was added and the solution was titrated against $0.25 \mathrm{MNaOH}$ with vigorous shaking until a permanent light pink colour was obtained. The acid value was calculated using Equation (4)

$$
\frac{100 \times 2.82 \times V}{W \times 1000 \times 4}
$$$$
\text { Percent acid value }=
$$

Where $\mathrm{W}=$ weight of oil $=1 \mathrm{~g}, \mathrm{~V}=$ titre value of $25 \mathrm{MaOH}, 2.82=$ equivalent weights of oleic acid

Determination of Peroxide value(PV): $5 \mathrm{~g}$ of oil sample was weighed into a conical flask and $30 \mathrm{ml}$ of a solvent mixture of glacial acetic acidchloroform in the ratio 3:2 respectively, were added to the oil sample. Half $\mathrm{ml}$ saturated $\mathrm{KI}$ solution was added to the solution and allowed to stand for 1minute. Thereafter, $30 \mathrm{ml}$ of distilled water was added and titrated with $0.1 \mathrm{~N}$ sodium thiosulphate solution using a starch indicator until the yellow colour was discharged. A blank was prepared alongside the oil sample. Peroxide value was calculated using equation 5 Peroxide value $=\frac{10 \times(V 1-V 2)}{M}$

$$
\text { ------------- } 5
$$

Where $\mathrm{V}_{1}=$ volume of $\mathrm{Na}_{2} \mathrm{~S}_{2} \mathrm{O}_{4}$ for the determination of test sample in $\mathrm{ml}$,

$\mathrm{V}_{2}=$ volume of $\mathrm{Na}_{2} \mathrm{~S}_{2} \mathrm{O}_{4}$ for the determination of blank solution in $\mathrm{ml}$,

$\mathrm{M}=$ mass of a test portion in $5 \mathrm{~g}$

\section{Data Analysis}

The physicochemical properties of the groundnut oils were determined at the biochemistry laboratory, department of biochemistry, Bayero University, Kano.The results obtained were compared with theNational Agency for Food and Drug Administration and Control (NAFDAC)standards using the Analysis of Variance (ANOVA).

\section{RESULTS AND DISCUSSION Investigation on the Extraction Methods Using Questionnaire}

It could be seen from Table 1 that the majority of the operators $(70 \%)$ in Sharada small-scale industries are youths of age range $25-30$ years. This simply implied that the operation of the industries is being carried out by vibrant and energetic youth. Also, most of the operators $(40 \%)$ were in the operation for $4-6$ years. This indicated that they have not been in the operation for a long period. Nevertheless, $60 \%$ of the operators obtained only secondary school knowledge and $20 \%$ acquired post-secondary school certificates.

The results showed that $60 \%$ of the industries were extracting the groundnut oil using groundnut variety 'Yar Dakar, 30\% Mai Bargo and others $(10 \%)$ use adifferentvariety of the groundnut. Probably the groundnut variety 'Yar Dakar best serves the interest of the industries. This agrees with the research by Muhammad et al., 2017 on some Engineering properties of three varieties of groundnut pods and kernels. Also, most of the industries $(60 \%)$ have an operational capacity of $0.5-1.0$ tonnes, $10 \%$ have $1.1-1.5$ tonnes, $10 \%$ have $2.1-5.0$ and $10 \%$ have greater or equal to 5.1 tonnes of groundnut per unit operation. Half (50\%) of the industries obtained a yield of fewer than 500 liters, 20\% collected 500-1000 liters, 20\% also collected $1500-2500$ liters and others (10\%) more than 2500 liters of the groundnut oil per unit operation.

Almost all of the industries (90\%) do not determine the quality of the extracted oil before market supply, only $10 \%$ do so.

It could also be seen that the majority ( $80 \%)$ of the small-scale industries employed the mechanical extraction method with roasting, while only $20 \%$ were found to roast the groundnut seeds before feeding it into the oil expelling machine. Ibrahim, (2010), reports that the majority roast the groundnuts before oil extraction as roasting influences extraction efficiency and extraction rate. Therefore, it has been proven to significantly influence these parameters.

There were five machines (screw-press oil expeller) types recorded during the investigation, which were generally used by the small-scale industries with a majority (30\%) of them employing a 100-Double Elephant model of the machines.Others, $20 \%$ used 100- Golden Star, $20 \%$ also used 130 -Golden Star, $10 \%$ used 130-Double Elephant, $10 \%$ also used 160Double Elephant and $10 \%$ used a combination of more than a single model of the screw-press oil expelling machine. Looking at the power requirements of the above-stated machines, $50 \%$ of the machinesconsume10-15 hp and the other $50 \%$ consumed $16-25 \mathrm{hp}$ from electrical energy. This implies that there is a gross underutilization of power, among the small-scale industries, incomparison to the operational capacity and the volume of extracted oil per unit tonne. 
BAJOPAS Volume 12 Number 1, June, 2019

Table 1: Results from the extraction processes investigation using a questionnaire

\begin{tabular}{|c|c|c|c|}
\hline Data description & Ranges & Frequency & Percentage (\%) \\
\hline \multirow[t]{4}{*}{ Operator's Age (years) } & $\leq 20$ & 1 & 10 \\
\hline & $21-24$ & 2 & 20 \\
\hline & $25-30$ & 7 & 70 \\
\hline & $\geq 31$ & - & - \\
\hline \multirow{4}{*}{$\begin{array}{l}\text { Operator's } \\
\text { Background }\end{array}$} & Non- formal & 1 & 10 \\
\hline & Primary & 1 & 10 \\
\hline & Secondary & 6 & 60 \\
\hline & Tertiary & 2 & 20 \\
\hline \multirow{4}{*}{$\begin{array}{l}\text { Operator's Working Experience } \\
\text { (years) }\end{array}$} & $\leq 3$ & 2 & 20 \\
\hline & $4-6$ & 4 & 40 \\
\hline & $6-9$ & 3 & 30 \\
\hline & $\geq 10$ & 1 & 10 \\
\hline \multirow[t]{3}{*}{ Groundnut variety } & Mai Bargo (Kampala) & 3 & 30 \\
\hline & $\begin{array}{l}\text { 'Yar Taraba ('Yar } \\
\text { Dakar) }\end{array}$ & 6 & 60 \\
\hline & Others & 1 & 10 \\
\hline \multirow[t]{5}{*}{ Operational Capacity (Tonnes) } & $0.5-1.0$ & 6 & 60 \\
\hline & $1.1-1.5$ & 1 & 10 \\
\hline & $1.6-2.0$ & - & - \\
\hline & $2.1-5.0$ & 1 & 10 \\
\hline & $\geq 5.1$ & 1 & 10 \\
\hline \multirow[t]{6}{*}{ Machine Make/Model } & 100- Golden Star & 2 & 20 \\
\hline & 130-Golden Star & 2 & 20 \\
\hline & 100-Double Elephant & 3 & 30 \\
\hline & 130-Double Elephant & 1 & 10 \\
\hline & 160-Double Elephant & 1 & 10 \\
\hline & Combination & 1 & 10 \\
\hline \multirow[t]{2}{*}{ Machine Power Requirement (Hp) } & $10-15$ & 5 & 50 \\
\hline & $16-25$ & 5 & 50 \\
\hline \multirow[t]{4}{*}{ Extraction Process } & $\begin{array}{l}\text { Mechanical with } \\
\text { Roasting }\end{array}$ & 2 & 20 \\
\hline & $\begin{array}{l}\text { Mechanical without } \\
\text { Roasting }\end{array}$ & 8 & 80 \\
\hline & Traditional & - & - \\
\hline & Solvent & - & - \\
\hline \multirow[t]{2}{*}{ Oil Quality Determination } & Yes & 1 & 10 \\
\hline & No & 9 & 90 \\
\hline \multirow{4}{*}{$\begin{array}{l}\text { Volume of Extracted Oil per unit } \\
\text { tonne (liters) }\end{array}$} & $\leq 500$ & 5 & 50 \\
\hline & $500-1500$ & 2 & 20 \\
\hline & $1500-2500$ & 2 & 20 \\
\hline & $>2500$ & 1 & 10 \\
\hline
\end{tabular}


BAJOPAS Volume 12 Number 1, June, 2019

\section{Physicochemical Analysis of Samples}

The mean data obtained in the laboratory were presented in Table 2.Tables 3 and 4 presents the results of ANOVA and LSD respectively.

\section{Iodine value}

Iodine value indicates oil stability and is used to determine the amount of unsaturation in fatty acids, which comes in the form of double bonds $(\mathrm{C}=\mathrm{C})$. According to Encyclopedia Britannica (2016), higher IV indicates ahigh unsaturationof fats in the oil and therefore the more reactive, less stable, softer, and more susceptible to oxidation and rancidity in the oil. Oils with high IV are desired by the oil industries (Sulaiman et al., 2012). The IV was not significantly affected by replication at a $5 \%$ probability level (Table 3 ). This indicated a minimal experimental error. But the methods of extraction have asignificant effect onIV at $1 \%$ probability level. It could also be observed in Table 4, thatM2 has the highest IV $(26.56 \mathrm{mg} / \mathrm{g})$ whereas the M3 has the least $(5.92 \mathrm{mg} / \mathrm{g})$. This implied that the groundnut oil from M3 could be best suitable for making soap. Meanwhile, IV obtained from all the three methods (Table 5) were far below the standard range of $86-107 \mathrm{mg} / \mathrm{g}$ as specified by NAFDAC (2005). Thus, the need for authorities to further investigate other quality indices to safeguard the populace by ensuring that only the best quality oil reaches the market.

\section{Saponification value}

The saponification value is the average molecular weight (chain length) of the fatty acids present in the oil. In combination with acid value, the saponification value is useful in providing information as to the quantity and mean weight of the acids in a given sample of oil (Sulaiman et al., 2012).A low value of the saponification value indicates the non-suitability of the oil in industrial use (Julius et al., 2013).It could be noticed from Table 3 that SV obtained from the three methods washighly significant. This simply implied that SV changes rapidly with changes in the extraction methods. Groundnut oil extracted using $M 1$, as in Table 4, has the highest SV $(168.295 \mathrm{mgKOH} / \mathrm{g})$ and M3 has the least $(44.835 \mathrm{mgKOH} / \mathrm{g})$. SV obtained (Table 2) for M1, M2 and M3 are similar to that obtained by Akinoso and Ekaette (2012). This implies that oil extracted using M1 has the shortest chain-length and that of M3 has the longest chain-length.However, SV obtained for all the three methodswas below the standard range of $187-196 \mathrm{mgKOH} / \mathrm{g}$ as given by NAFDAC (2005).

\section{Acid Value}

The acid value indicates the quality of fatty acids in theoil. It represented the milligram $\mathrm{KOH}$ required to neutralize the free fatty acid in $1 \mathrm{~g}$ of oil. The low acid value ofthe oil indicates that the oil will be stable over a long period and protect against rancidity and peroxidation (Aremuet al., 2015). The acid value is also used as an indicator ofthe edibility of an oil and suitability for use in the paint and soap industries. The high acid value of theoil indicates that the oil may not be suitable for use in cooking (edibility).Instead, could be used for the production of paints, liquid soap, and shampoos.AV obtained for all the three replicates and methods (M1, M2, and M3) were not significant (Table 3). AV obtained (Table 2) were similar to that obtained by Aluyoret al., (2009). Moreover, AV was found to be within the standard range of not more than $0.6 \mathrm{mg} \mathrm{KOH} / \mathrm{g}$ as stipulated by NAFDAC (2005).

\section{Peroxide Value}

Peroxide value (PV) is the most common indicator of lipid oxidation (Aremuet al., 2015). PV is used as a measure of the extent to which rancidity (emission of unpleasant taste and odour) reactions have occurred during storage and can be used as an indication of the quality and stability of fats and oils (Zahiret al., 2014). It could be seen (Table 3) that PV is highly significant (meaning that rapid change in PV occurs proportionately withachange in the extraction method); with M2 having the highest PV (5.7 meq kg ${ }^{-1}$ ) and M3 has the least (Table 4).PV obtained for $M 2\left(5.7 \mathrm{meqkg}^{-1}\right)$, as can be seen in Table 2, was similar to that obtained by Akinoso and Ekaette (2012). Meanwhile, PV was found to be within the standard range (of not more than $10 \mathrm{meqkg}^{-1}$ ) given by NAFDAC (2005).

\section{Specific Gravity}

Specific gravity (SG) is the comparison of the weight of the oil to that of water having the same volume and at a given temperature. Aslam-Shad et al., (2012) described the specific gravity of oils as the ratio of the density of oil to that of water. Specific gravity is also termed relative density, which is often preferred in modern scientific usage. SG measurement is particularly useful because it allows access to molecular information in a non-invasive way (Sulaiman et al., 2012).

SG was found (as in Table 3) to be nonsignificant across M1, M2, and M3. SG from the laboratory analysis (Table 2) was found to be similar to that found by Sulaiman et al., (2012). The values of SG were also within the standard range of $0.912-0.920$ as stated by NAFDAC (2005). 
BAJOPAS Volume 12 Number 1, June, 2019

Table 2: Physicochemical properties of the groundnut oil

\begin{tabular}{|c|c|c|c|c|c|}
\hline \multirow{2}{*}{ METHOD } & \multicolumn{5}{|c|}{ PHYSICOCHEMICAL PARAMETERS } \\
\hline & IV $(\mathbf{m g} / \mathrm{g})$ & SV(mgKOH/g) & $\mathrm{AV}(\mathrm{mgKOH} / \mathrm{g})$ & PV (meq/ kg) & SG \\
\hline M1 & 23.675 & 168.295 & 0.145 & 4.35 & 0.911 \\
\hline M2 & 26.56 & 106.605 & 0.19 & 5.7 & 0.9115 \\
\hline M3 & 5.92 & 44.835 & 0.155 & 0.75 & 0.91075 \\
\hline \multicolumn{6}{|c|}{ Table 3: Analysis of variance for the methods } \\
\hline & $\operatorname{IV}(\mathbf{m g} / \mathrm{g})$ & SV(mgKOH/g) & $\mathrm{AV}(\mathrm{mgKOH} / \mathrm{g})$ & $\operatorname{PV}(\mathbf{m e q} / \mathbf{k g})$ & SG \\
\hline Rep & $1.03^{\mathrm{NS}}$ & $0.44^{\mathrm{NS}}$ & $1.49 \mathrm{NS}$ & 16.00 NS & 0.00 NS \\
\hline Method & $4365.17 * *$ & $1.225 \mathrm{E} 7 * *$ & $4.67^{\mathrm{NS}}$ & $23571^{* *}$ & $3.00^{N S}$ \\
\hline
\end{tabular}

Table 4: LSD comparison for mean values

\begin{tabular}{crrrrrr}
\hline LEVELS & \multicolumn{2}{c}{ IV (mg/g) } & \multicolumn{2}{c}{ SV (mgKOH/g) } & \multicolumn{2}{c}{ PV(meq/ kg) } \\
\hline A & M2 & 26.56 & M1 & 168.295 & M2 & 5.7 \\
B & M1 & 23.675 & M2 & 106.605 & M1 & 4.35 \\
C & M3 & 5.92 & M3 & 44.835 & M3 & 0.75 \\
\hline
\end{tabular}

$\mathrm{A}=$ highest, $\mathrm{B}=$ medium and $\mathrm{C}=$ lowest

Table 5: Comparison of parameters

\begin{tabular}{cccc}
\hline $\begin{array}{c}\text { Physicochemical } \\
\text { Parameters }\end{array}$ & $\begin{array}{c}\text { Laboratory } \\
\text { Determined }\end{array}$ & NAFDAC Standard & Comment \\
\hline Iodine Value $(\mathrm{mg} / \mathrm{g})$ & $2.92-26.56$ & $86-107$ & Below Standard \\
Saponification Value & $44.85-168.295$ & $187-196$ & Below Standard \\
$(\mathrm{mgKOH} / \mathrm{g})$ & $0.145-0.19$ & $\leq 0.6$ & Within standard \\
Acid Value $(\mathrm{mgKOH} / \mathrm{g})$ & $0.75-5.7$ & $\leq 10$ & Within standard \\
Peroxide Value $(\mathrm{meq} / \mathrm{kg})$ & $0.910-0.911$ & $0.912-0.920$ & Within standard \\
Specific Gravity & & & \\
\hline
\end{tabular}

\section{CONCLUSION}

From the overall study, it could be concluded that the extraction of oil among the industries was associated with a gross underutilization of power since the relatively similar operational capacity was obtained by the industries while having a high difference power usage (given in horsepower). The extraction methods significantly affected the physicochemical properties. The mechanical extraction method with roasting proved to havethe best quality whereas the traditional extraction method proves the least.In comparison to NAFDAC standard, AV, PV, and SG are concluded to be within the specified ranges, while IV and SV declined. Hence the groundnut oils are safe for human consumption and may seek application in industrial uses.

\section{RECOMMENDATIONS}

During the investigation undertaken, less emphasis was given to the identification of the best machine make/model that gives the highest yield of groundnut oil suitable for small-scale industries. Further researches should be carried out to make such information available to the stakeholders. Since M3 was found to be the least in all the identified physicochemical properties, it is recommended that researcheson this aspect should be carried. Also, research should be carried out to find out whether the elimination of roasting in $\mathrm{M} 1$ is the sole reason that caused M2 to possess higher quality.

As the study noted some decline and nonconformance to the standards, it is recommended that the small-scale industries should review the steps followed in the 
BAJOPAS Volume 12 Number 1, June, 2019

extraction processes for rectification. It is also recommended that research should be carried out to evaluate the knowledge of food processing related standards among the smallscale industries, in order to comply with the standards. Further researches should assess the level of pre-extraction stages among the smallscale industries, whether it has an impact on

\section{REFERENCES}

Akinoso, R and EkaetteI.U. (2012); Natural Additives Effects on Some Quality Parameters of Un-Refined Peanut Oil. African Journal of Food, Agriculture, Nutrition and Development (AJFND) 12(6): 6715-6736

Aluyor, E. O., Aluyor, P. and Ozigagu, C. E. (2009). Effect of Refining on the Quality and Composition of Groundnut Oil. African Journal of Food Science, 3(8): 201-205. Available online at http://www.academicjournals.org/ajfs ISSN 1996-0794

AOCS (1998). Official and Tentative Methods of American Oil Chemists Society (Ed) Champion IL, USA.

Aremu, M. O., Ibrahim, H. and Bamidele, T. O. (2015); Physicochemical Characteristics of the Oils Extracted from Some Nigerian Plant Foods- A Review. Chemical and Process Engineering Research, 32: 36-52

Aslam-Shad, M., Pervez, H., Iqbal Zafar, Z., Nawaz, H. and Khan, H. (2012); Physicochemical Properties, Fatty Acid Profile and Antioxidant Activity of Peanut Oil. Pakistan Journal Botany, 44(1): 435-440

Britannica Encyclopaedia (2016). Iodine Value. Available online at https://www.britannica.com/science/iodinevalue [accessed 2016-08-31 at 03:50PM].

Chabiri, S.A., Hati, S.S., Dimari, G.A., and Ogugbuaja, V.O (2009). Comparative Quality Assessment of Branded and Unbranded Edible Vegetable Oils in Nigeria. The Pacific Journal of Science and Technology 10(2): 927-934.

FAO Food and Agriculture Organization (2002). Groundnuts: Post harvest Operations. INPho Post-Harvest Compendium.

Ibrahim, A. and Onwualu, A. P. (2005). Technologies for Extraction of Oil from OilBearing Agricultural Products: A Review. Journal of Agricultural Engineering and Technology (JAET) 13: 58-70

Ibrahim, I. I (2010). A Study on the Traditional Groundnut Oil Extraction Method: A Case Study of Dawanau Town. An Unpublished B. Eng Thesis Submitted to the Department of Agricultural and Environmental Engineering, Bayero University, Kano. both the yield and quality of groundnut oil or not.

\section{CONTRIBUTION OF AUTHORS:}

All the authors involved in this paper have contributed to the success of this study.

CONFLICT OF INTEREST: The authors declare that there is no conflict of interest.

ICRISAT International Crops Research Institute for the Semi-Arid Tropics and East-Timor, (2003). Groundnut Agriculture: New Directions for a New Nation East Timor (Timor-Leste). (Ed) ACIAR Proceedings No. 113

Julius, K.I., Lilly, N.U and Ayangealumun, I (2013). Effects of Extraction Methods on the Yield and Quality Characteristics of Oils from Shea Nut. Journal of Food Resource Science 2(1):1-12.

Matola, A., Masamba, K., Mwangwela, A and Mlotha, V (2015). Quality Evaluation of Sunflower and Groundnut Oil Produced by Two Cooperatives Under the One Village One Product Programme in Central Malawi. African Journal of Agricultural Research (AJAR) 10 (11):1338-1343.

Muhammad, Aliyu Idris., Ahmad, Rabi Kabir and Lawan, Ibrahim. (2017) Effect of moisture content on some engineering properties of groundnut pods and kernels.AgricEngInt: CIGR Journal Open access at http://www.cigrjournal.orgDecember, 2017. Vol. 19, No. 4: 200-208

NAFDAC National Agency for Food and Drug Administration and Control, Fats and Oils Regulations (2005)

Sulaiman, M.M., Bello, A.U., Itumoh, J. E., Bello, K., Bello A. M andArzika, A.T. (2012). Physicochemical Properties of Some Commercial Groundnut Oil Products Sold in Sokoto Metropolis, Northwest Nigeria. Journal of Biological Science and Bioconservation. 4: 38-45.

Vara-Parasad, P.V., Kakani, V.G and Upadhyaya, H.D (2011). Growth and Production of Groundnuts. Soils, Plant growth and Crop Production Volume II. Available online at http://www.eolss.net/EolsssampleAllChapters.aspx

Zahir, E., Saeed R., Abdul Hameed M. and Yousuf A. (2014). Study of Physicochemical Properties of Edible Oil and Evaluation of Frying Oil Quality by Fourier TransformInfrared (FT-IR) Spectroscopy. Arabian Journal of Chemistry available online at http://dx.doi.org/10.1016/j.arabjc.2014.05.0 25 
BAJOPAS Volume 12 Number 1, June, 2019 